\author{
Filip Grzegorczyk \\ Katedra Rachunkowości \\ Uniwersytet Ekonomiczny w Krakowie
}

Jerzy Hejnar

Katedra Rachunkowości Finansowej

Uniwersytet Ekonomiczny w Krakowie

\title{
Spelnienie wymogu niezależności członków rad nadzorczych w procesie zapewnienia jakości rewizji finansowej
}

\section{Streszczenie}

Właściwy tryb powołania biegłego rewidenta w obrocie gospodarczym oraz jego kompetencje merytoryczne i etyczne stanowią warunek konieczny efektywności rewizji finansowej. Działalność biegłego rewidenta może być jednak optymalizowana, gdy po stronie badanego podmiotu (jednostki) odnajduje on właściwych partnerów merytorycznych. Poza członkami zarządu dotyczy to również członków rad nadzorczych. Zarysowujący się trend wzmacniania roli organów nadzoru korporacyjnego w szeroko rozumianym procesie sprawozdawczości i rewizji finansowej znajduje wyraz w przepisach ustawy o rachunkowości (np. w art. 4a tej ustawy). Przedmiotem opracowania jest ustalenie podstawowego kryterium pozwalającego przyjąć, że biegły rewident może odnaleźć partnera merytorycznego w procesie rewizji finansowej (kryterium tym jest niezależność członków rad nadzorczych). Celem opracowania jest także zbadanie stopnia występowania zjawiska niezależności członków rad nadzorczych w wybranych grupach spółek publicznych notowanych na Giełdzie Papierów Wartościowych w Warszawie.

Słowa kluczowe: ład korporacyjny, niezależność członków rad nadzorczych, rewizja finansowa, badanie statutowe. 


\section{Wstęp}

Rola biegłego rewidenta w obrocie gospodarczym jest oczywista (zob. [Garstka 2011, Kutera 2008]). Właściwy tryb powołania oraz kompetencje merytoryczne i etyczne biegłego rewidenta stanowią conditio sine qua non efektywnego realizowania zadań stojących przed rewizją finansową. Należy jednak zauważyć, że działalność biegłego rewidenta może być optymalizowana, gdy po stronie badanego podmiotu (jednostki) odnajduje on właściwych partnerów merytorycznych. Poza członkami zarządu na szczególną uwagę zasługują członkowie rad nadzorczych. Zarysowujący się trend wzmacniania roli organów nadzoru korporacyjnego w szeroko rozumianym procesie sprawozdawczości i rewizji finansowej znajduje wyraz w przepisach ustawy o rachunkowości [Oplustil 2010, s. 183-276] ${ }^{1}$. Celem opracowania jest analiza regulacji prawnej odnoszącej się do niezależności członków rad nadzorczych oraz analiza poziomu przestrzegania przedmiotowej regulacji w praktyce spółek publicznych notowanych na GPW w Warszawie.

\section{Niezależność członków rady nadzorczej jako podstawowy wymóg mający wpływ na jakość rewizji finansowej - ujęcie normatywno-jakościowe}

Rada nadzorcza w dualistycznym systemie ${ }^{2}$ ładu korporacyjnego stanowi organ, któremu przypisano funkcję nadzoru nad działalnością spółki. Zgodnie z art. 381 k.s.h. ${ }^{3}$ w spółce akcyjnej obligatoryjnie powołuje się radę nadzorczą, a art. $382 \S 1$ k.s.h. określa jej podstawową kompetencję, tj. sprawowanie stałego nadzoru nad działalnością spółki we wszystkich dziedzinach jej działalności. Poza tym ogólnym przepisem kodeks wskazuje też w katalogu otwartym inne kompetencje rady nadzorczej, np. ocenę sprawozdań, o których mowa w art. 395 § 2 pkt 1 (w zakresie ich zgodności z księgami i dokumentami, jak również ze stanem faktycznym, oraz wniosków zarządu dotyczących podziału zysku albo pokrycia

1 Zob. art. 4a Ustawy z dnia 29 września 1994 r. o rachunkowości, Dz.U. 2013, poz. 330.

2 System dualistyczny sprowadza się do przypisania funkcji zarządzania (reprezentacji i prowadzenia spraw spółki) i funkcji nadzoru odrębnym organom korporacyjnym, tj. odpowiednio zarządowi i radzie nadzorczej. Funkcjonuje on częściowo we Francji oraz w niemieckim kręgu kultury prawnej. Przeciwieństwem tego systemu jest system monistyczny, obecnie obowiązujący zasadniczo przede wszystkim w krajach należących do anglosaskiej kultury prawnej, a częściowo też we Francji. Funkcja zarządzania i nadzoru przypisana jest jednemu organowi (radzie dyrektorów, radzie administrującej), w ramach której wyróżnia się dyrektorów wykonawczych (w tym CEO i CFO) oraz niewykonawczych.

${ }^{3}$ Ustawa z dnia 15 września 2000 r. Kodeks spółek handlowych, Dz.U. nr 94, poz. 1037 ze zm. 
straty), składanie walnemu zgromadzeniu corocznego pisemnego sprawozdania $\mathrm{z}$ wyników tej oceny ${ }^{4}$, a także zawieszanie, $\mathrm{z}$ ważnych powodów, w czynnościach poszczególnych lub wszystkich członków zarządu oraz delegowanie członków rady nadzorczej, na okres nie dłuższy niż trzy miesiące, do czasowego wykonywania czynności członków zarządu, którzy zostali odwołani, złożyli rezygnację albo z innych przyczyn nie mogą sprawować swoich czynności ${ }^{5}$. Kompetencje rady nadzorczej mogą ulegać rozszerzeniu w drodze postanowień statutu ${ }^{6}$, co stanowi oczywiste potwierdzenie tezy, że układ kodeksowy zakreślił jedynie minimalny poziom uprawnień rady nadzorczej. Z kolei poszerzenie kompetencji rady nadzorczej trzeba traktować jako nadanie konkretnej treści ogólnemu postanowieniu art. $382 \S 1$ k.s.h.

Rada nadzorcza stanowi zatem potencjalnie istotny organ korporacyjny o daleko idących uprawnieniach. Rozszerzanie uprawnień rady nadzorczej ma jednak swoje granice, tj. nie powinna ona przejmować kompetencji w zakresie prowadzenia spraw spółki i jej reprezentowania, co zdaje się wynikać wprost z art. $368 \S 1$ k.s.h., stanowiącego, że to zarząd prowadzi sprawy spółki i ją reprezentuje. Jest to przepis, który należy rozumieć jako wskazujący podstawową normę kompetencyjną zarządu. Przepis ten można także rozumieć w sposób gwarancyjny - uniemożliwia on takie rozszerzenie kompetencji rady nadzorczej, w której zarząd faktycznie zostałby pozbawiony racji bytu. Należy podkreślić, że wobec jednoznacznej decyzji ustawodawcy odnośnie do funkcjonowania dualistycznego modelu ładu korporacyjnego spółek akcyjnych w polskim porządku prawnym statutowe ,unicestwienie” zarządu jako organu prowadzącego sprawy spółki i ją reprezentującego trzeba by uznać za sprzeczne z ustawą lub co najmniej mające na celu jej obejście, a tym samym za nieważne ${ }^{7}$.

Pomijając rozważania dotyczące granic kompetencji rady nadzorczej, warto zaakcentować przede wszystkim jej nadzorczy charakter. Powszechnie przyjmuje się, że właściwe wykonywanie tej funkcji wymaga w pierwszej kolejności zachowania niezależności członków rady nadzorczej. Problematyka ta jest główną osią rozważań zawartych w tym opracowaniu.

Wykonywanie funkcji nadzoru nad działalnością spółki musi rodzić pytanie o celowość jej realizacji, szczególnie z punktu widzenia różnych uczestników życia gospodarczego (rozumianych szeroko jako akcjonariusze, potencjalni inwestorzy czy organy władzy publicznej). W kwestii pierwszej z wymienionych grup

\footnotetext{
${ }^{4}$ Art. $382 \S 3$ k.s.h.

5 Art. $383 \S 1$ k.s.h.

${ }^{6}$ Art. $384 \S 1$ k.s.h.

7 Art. 58 § 1 Ustawy z dnia 18 maja 1964 r. Kodeks cywilny, Dz.U. nr 16, poz. 93 ze zm.,
} dalej k.c. 
już na wstępie należy zastrzec występowanie zróżnicowanych sytuacji. Jeżeli przedmiotem analizy jest prywatna, jednoosobowa spółka akcyjna, a akcjonariusz zasiada w zarządzie, funkcja rady nadzorczej może zostać łatwo sprowadzona do funkcji legitymowania na zewnątrz poczynań tegoż akcjonariusza. Trudno jednak racjonalnie zakładać, by akcjonariusz obsadzający poprzez walne zgromadzenie skład rady nadzorczej pozwolił jej członkom na zbyt daleko idącą kontrolę samego siebie. Pewną mutacją pierwszego wariantu jest sytuacja, gdy jedyny akcjonariusz zasiada w radzie nadzorczej (najczęściej jako jej przewodniczący). Wtedy ciężar decyzyjny w spółce przesuwa się w kierunku rady właśnie, natomiast zarząd pozostaje organem zarządzającym jedynie operacyjnie. Taki układ powoduje jednak marginalizację rady nadzorczej, ponieważ za bardzo ingeruje ona w funkcje, które powinny pozostawać wyłączną domeną zarządu.

Nieco inaczej sytuacja może przedstawiać się w przypadku spółek publicznych, wśród których nie występuje spółka jednoosobowa. Często jednak istnieje tzw. akcjonariusz dominujący ${ }^{8}$, obok akcjonariuszy mniejszościowych oraz abstrakcyjnego rynku uosabianego przez potencjalnych inwestorów. Każdy z wymienionych podmiotów ma swoje - często odmienne - interesy. Akcjonariusz dominujący de facto kontroluje spółkę, co przejawia się jego wpływem na obsadę rady nadzorczej (bezpośrednim) i zarządu (pośrednim). Można zatem przyjąć istnienie istotnego wpływu takiego akcjonariusza na prowadzenie spraw spółki. Akcjonariusz ten ma swoje cele i w związku z tym nie zawsze jest chętny do pełnego stosowania zasady przejrzystości. Z kolei akcjonariusze mniejszościowi przede wszystkim muszą dbać o to, by decyzje akcjonariusza dominującego nie były dla nich niekorzystne. Wiedza na temat działań i sytuacji spółki jest warunkiem koniecznym ochrony ich praw. W końcu potencjalni inwestorzy, którzy rozważają powierzenie spółce publicznej swojego kapitału, mają w pełni uzasadnione prawo do pozyskania odpowiedniej wiedzy.

Zarysowana gra interesów czyni z zasady przejrzystości główną oś podziału. Dodać należy, że w grę wchodzi jeszcze ochrona interesu publicznego, który słusznie sprowadzić można do pojęcie zaufania na rynku kapitałowym [Śliwińska-Grzegorczyk 2011, s. 144-159]. Powstaje więc pytanie, jakie środki prawne mogą najlepiej służyć ochronie tego interesu, a także potencjalnym inwestorom i akcjonariuszom mniejszościowym.

Autorzy artykułu zgadzają się ze stanowiskiem, że jednym z elementów skutecznego wykonywania nadzoru korporacyjnego, a także elementem budu-

\footnotetext{
8 Akcjonariusz dominujący rozumiany jest w tym opracowaniu jako akcjonariusz, który skupił w swym ręku ilość akcji dającą mu w określonym czasie kontrolę nad spółką. Nie musi to więc być akcjonariusz większościowy, a to wobec częstego rozproszenia pozostałej części akcjonariatu.
} 
jącym zaufanie do rynku kapitałowego i spółek publicznych jest powoływanie niezależnych członków rad nadzorczych [Oplustil 2010, s. 432-436]9 .

Niezależność członków rad nadzorczych została uregulowana w następujących dokumentach ${ }^{10}$ :

1) art. 86 u.b.r. ${ }^{11}$,

2) Uchwała nr 19/1307/2012 Rady Giełdy Papierów Wartościowych w Warszawie $\mathrm{z}$ dnia 21 listopada 2012 r. $^{12}$

Art. 86 ust. 1 u.b.r. przewiduje, że w tzw. jednostkach zainteresowania publicznego ${ }^{13}$ powoływany jest (zasadniczo) w radzie nadzorczej komitet do spraw audytu. Nawiasem mówiąc, sposób uregulowania tego komitetu w prawie polskim spotkał się z daleko idącą krytyką (zob. [Grzegorczyk 2010a, s. 114-136; 2010b, s. 39-46]). Skład tego komitetu, zgodnie z art. 86 ust. 4 u.b.r., tworzy trzech członków, w tym przynajmniej jeden z nich powinien spełniać warunki niezależności i posiadać kwalifikacje w dziedzinie rachunkowości lub rewizji finansowej. Art. 86 ust. 5 u.b.r. wskazuje, że odnośnie do spełniania warunków niezależności członka komitetu audytu stosuje się odpowiednio przepisy art. 56 ust. 3 pkt 1, 3 i 5 u.b.r. Oznacza to, że niezależny członek komitetu do spraw audytu (i tym samym rady nadzorczej) to osoba, która:

a) nie posiada udziałów, akcji lub innych tytułów własności w jednostce, w której radzie nadzorczej zasiada (dotyczy także jednostki powiązanej);

b) nie uczestniczyła w ostatnich 3 latach w prowadzeniu ksiąg rachunkowych lub sporządzaniu sprawozdania finansowego jednostki, w której radzie nadzorczej zasiada;

c) nie jest małżonkiem, krewnym lub powinowatym w linii prostej do drugiego stopnia lub nie jest związany z tytułu opieki, przysposobienia lub kurateli z osobą będącą członkiem organów nadzorujących, zarządzających lub administrujących jednostki, w której radzie nadzorczej zasiada.

${ }^{9}$ Co szczególnie mocno akcentowane jest w odniesieniu do członków rad zasiadających w komitetach do spraw audytu, zob. Section 10 (m) (2) amerykańskiej Securities Exchange Act.

10 Autorzy wymieniają akty, które mają zastosowanie do spółek notowanych na Giełdzie Papierów Wartościowych w Warszawie.

${ }^{11}$ Ustawa z dnia 7 maja 2009 r. o biegłych rewidentach i ich samorządzie, podmiotach uprawnionych do badania sprawozdań finansowych oraz o nadzorze publicznym, Dz.U. nr 77, poz. 649 ze zm.

12 Załącznik „Dobre praktyki spółek notowanych na GPW” przywoływany jako Zasady.

13 Jednostki zainteresowania publicznego to m.in. spółki publiczne, czyli mający siedzibę na terytorium Rzeczypospolitej Polskiej emitenci papierów wartościowych dopuszczonych do obrotu na rynku regulowanym państwa Unii Europejskiej, z wyłączeniem jednostek samorządu terytorialnego (zob. art. 2 pkt. 4 ppkt (a) u.b.r.). 
Sposób sformułowania przepisu budzi wątpliwości. Swoje źródło mają one w sformułowaniu: „przynajmniej jeden z nich powinien [podkr. aut.] spełniać warunki niezależności i posiadać kwalifikacje w dziedzinie rachunkowości lub rewizji finansowej”. Określenie „powinien” może sugerować istnienie normy o charakterze jedynie instrukcyjnym. Brak sankcji stosowanych na wypadek niespełnienia przez spółki tego wymogu oraz wykładnia językowa nakazują przychylenie się do tezy, że norma ta ma w faktycznie taki charakter. Z kolei wykładnia teleologiczna może sugerować imperatywny charakter normy.

Próbując rozwikłać ten problem, należy wyjść od stwierdzenia, że skład i kompetencje rady nadzorczej uregulowane zostały in principio w k.s.h. (lex generalis), natomiast przepisy u.b.r. dotyczące składu i kompetencji rady nadzorczej (w tym i komitetu do spraw audytu) mają charakter szczególny, wyjątkowy (lex specialis). Podstawowe reguły wykładni prawa nakazują przyjąć, że wyjątki nie mogą podlegać wykładni rozszerzającej. Wobec tego, skoro przepis nie został sformułowany jednoznacznie (tj. nie brzmi ,przynajmniej jeden z nich spełnia warunki niezależności i posiada kwalifikacje w dziedzinie rachunkowości lub rewizji finansowej"), nie jest uprawnione przyjmowanie dla tego przepisu wykładni dalej idącej, czyli imperatywnej. Wykładnia językowa tezę tę potwierdza.

W związku z tym, wbrew zamierzeniom prawodawcy unijnego ${ }^{14}$, spełnienie warunku niezależności i kwalifikacji w dziedzinie rachunkowości lub rewizji finansowej przez członków rady nadzorczej nie jest konieczne w rozumieniu u.b.r. Oznacza to, że spółki notowane na warszawskiej giełdzie, informując o niezależnych członkach rad nadzorczych, nie mają na myśli członków niezależnych w rozumieniu u.b.r., lecz członków niezależnych w rozumieniu „Dobrych praktyk spółek notowanych na GPW". Co gorsza, wydaje się, że redakcja omawianego przepisu u.b.r. nie czyni zadość obowiązkowi przeniesienia stosownych przepisów dyrektywy do prawa polskiego. Niestety, autorzy nawet najobszerniejszych opracowań na wskazany temat problem ten pomijają (zob. np. [Andrzejewski 2012, s. 186]).

Przyjęte uchwałą Rady Giełdy „Dobre praktyki spółek notowanych na GPW” także odnoszą się do niezależności członków rad nadzorczych spółek publicznych. Zgodnie z zasadą III.6 tego dokumentu przynajmniej dwóch członków rady nadzorczej powinno spełniać kryteria niezależności od spółki i podmiotów pozostających $w$ istotnym powiązaniu ze spółką ${ }^{15}$. W zakresie kryteriów niezależności członków rady nadzorczej powinien być stosowany Załącznik II do Zalecenia

14 Zob. Dyrektywę 2006/43/WE Parlamentu Europejskiego i Rady z dnia 17 maja 2006 r. w sprawie ustawowych badań rocznych sprawozdań finansowych i skonsolidowanych sprawozdań finansowych, zmieniającą dyrektywy Rady 78/660/EWG i 83/349/EWG oraz uchylającą dyrektywę Rady 84/253/EWG, Dz.U. L 157 z 9.06.2006.

15 W opracowaniu pominięto inne postanowienia Zasad, w szczególności przewidujące obowiązki informacyjne członków rad dotyczące ich powiązań. 
Komisji Europejskiej z dnia 15 lutego 2005 r. dotyczącego roli dyrektorów niewykonawczych lub będących członkami rady nadzorczej spółek giełdowych i komisji rady (nadzorczej). Zalecenie to jasno wskazuje, że sformułowane kryteria nie są wyczerpujące, a do stwierdzenia niezależności należy stosować zasadę przewagi treści nad formą. Kryteria niezależności wymienia Załącznik II, pkt 1 ppkt a-i, przy czym Zasady zaostrzają kryteria wynikające z Zalecenia w ten sposób, że osoba będąca pracownikiem spółki, podmiotu zależnego lub podmiotu stowarzyszonego nie może być uznana za spełniającą kryteria niezależności.

Kryteria niezależności członka rady nadzorczej zawarte w Załączniku II do Zalecenia Komisji Europejskiej z dnia 15 lutego 2005 r. są następujące:

„a) Osoba nie jest dyrektorem wykonawczym lub zarządzającym spółki lub spółki stowarzyszonej i nie piastowała takiego stanowiska w ciągu ostatnich pięciu lat.

b) Osoba nie jest pracownikiem spółki lub spółki stowarzyszonej; nie była w takiej sytuacji w ciągu ostatnich trzech lat, z wyjątkiem sytuacji, kiedy dyrektor niewykonawczy lub będący członkiem rady nadzorczej nie należy do kadry kierowniczej wysokiego szczebla lub został wybrany do rady (nadzorczej) w kontekście systemu przedstawicielstwa pracowniczego uznanego prawem i przewidującego odpowiednią ochronę przed niesłusznym zwolnieniem i innymi formami niesprawiedliwego traktowania.

c) Osoba nie otrzymuje ani nie otrzymała dodatkowego wynagrodzenia, w znaczącej wysokości, od spółki lub spółki stowarzyszonej, oprócz wynagrodzenia otrzymywanego jako dyrektor niewykonawczy lub członek rady nadzorczej. Takie dodatkowe wynagrodzenie obejmuje w szczególności udział w systemie przydziału opcji na akcje lub w innym systemie wynagradzania za wyniki; nie obejmuje otrzymywania kwot wynagrodzenia w stałej wysokości w ramach planu emerytalnego (w tym wynagrodzenia odroczonego) z tytułu wcześniejszej pracy w spółce (pod warunkiem, że warunkiem wypłaty takiego wynagrodzenia nie jest kontynuacja zatrudnienia).

d) Osoba nie jest akcjonariuszem lub nie reprezentuje w żaden sposób akcjonariusza(-y) posiadającego(-ych) pakiet kontrolny (gdzie kontrolę ustala się przez odesłanie do przypadków wspomnianych w art. 1 ust. 1 dyrektywy Rady 83/349/ EWG (1)).

e) Osoba nie utrzymuje obecnie ani nie utrzymywała w ciągu ostatniego roku znaczących stosunków handlowych ze spółką lub spółką stowarzyszoną, bezpośrednio lub w charakterze wspólnika, akcjonariusza, dyrektora lub pracownika wysokiego szczebla organu utrzymującego takie stosunki. Stosunki handlowe obejmują sytuację bycia znaczącym dostawcą towarów lub usług (w tym usług finansowych, prawnych, doradczych lub konsultingowych), znaczącym klientem i organizacją, która otrzymuje znacznej wysokości wkłady od spółki lub jej grupy. 
f) Osoba nie jest obecnie lub w ciągu ostatnich trzech lat nie była wspólnikiem lub pracownikiem obecnego lub byłego rewidenta zewnętrznego spółki lub spółki stowarzyszonej.

g) Osoba nie jest dyrektorem wykonawczym lub zarządzającym w innej spółce, w której dyrektor wykonawczy lub zarządzający spółki jest dyrektorem niewykonawczym albo członkiem rady nadzorczej, i nie posiada innych znaczących powiązań z dyrektorami wykonawczymi spółki przez udział w innych spółkach lub organach.

h) Osoba nie pełniła funkcji w radzie (nadzorczej) jako dyrektor niewykonawczy lub dyrektor będący członkiem rady nadzorczej dłużej niż przez trzy kadencje (lub dłużej niż 12 lat, kiedy prawo krajowe przewiduje bardzo krótki wymiar normalnych kadencji).

i) Osoba nie jest członkiem bliskiej rodziny dyrektora wykonawczego lub zarządzającego, lub osób w sytuacjach opisanych w lit. a)-h)"16.

We wskazanych dokumentach inaczej postrzegana jest kwestia niezależności. Pierwsza różnica dotyczy ich mocy prawnej. Ustawa o biegłych rewidentach ma moc powszechnie obowiązującą, co oznacza, że w każdej radzie nadzorczej spółki publicznej powinien (choć nie musi) pojawić się co najmniej jeden członek spełniający omawiany wymóg w rozumieniu u.b.r. Z kolei według postanowień Zasad w radzie nadzorczej spółki publicznej zasiadać musi co najmniej dwóch członków spełniających wymóg niezależności (ale w rozumieniu Zasad), przy czym realizacja postanowień Zasad opiera się na regule comply or explain - trudno zatem przyjąć jej imperatywny charakter. Trzecia różnica dotyczy ostrości kryteriów - choćby pobieżna analiza wskazuje, że kryteria ostrzejsze wynikają z Zasad, natomiast u.b.r. posługuje się standardem absolutnego minimum. Wynika z tego, że osoba spełniająca wymóg niezależności w rozumieniu u.b.r. niekoniecznie musi je spełnić w rozumieniu Zasad ${ }^{17}$.

Paradoksalnie zatem okazuje się, że ze względu na redakcję przepisów u.b.r. to Zasady, a nie ustawa mająca wdrożyć dyrektywę 2006/43/WE, zyskują pierwszeństwo. Sytuacja taka nie służy budowaniu zaufania do porządku prawnego i funkcjonowania rynku kapitałowego. Wydaje się, że decydenci mający wpływ na funkcjonowanie danego obszaru życia społeczno-gospodarczego (w tym przypadku spółek publicznych) powinni dążyć do maksymalnej unifikacji regulacji prawnych, by eliminować wątpliwości i wprowadzać jeden, wysoki i imperatywny standard.

16 Zalecenie Komisji z dnia 15 lutego 2005 r. dotyczące roli dyrektorów niewykonawczych lub będących członkami rady nadzorczej spółek giełdowych i komisji rady (nadzorczej) 2005/162/WE, Dz.Urz. UE L 52.

17 Jest to jednak temat zasługujący na odrębne opracowanie. 


\section{Niezależność członków rady nadzorczej jako podstawowy wymóg mający wpływ na jakość rewizji finansowej - ujęcie ilościowe}

Pozostawiając na uboczu merytoryczne kryteria niezależności (przyjąwszy roboczą hipotezę, że członek rady zgłoszony jako niezależny faktycznie spełnia ten wymóg), warto skoncentrować się na kwestii liczby niezależnych członków rady. Ustawa o biegłych wprowadza w tym zakresie wymóg jednej osoby, a Zasady - dwóch osób. Obie liczby należy uznać za wymóg minimalny. Czy jednak jest on adekwatny do istniejącego stanu rzeczy? Albo inaczej - czy spełnienie wymogu minimalnego daje wystarczająco silne podstawy, by uznać, że założone cele zostaną osiągnięte?

Autorzy opracowania przeprowadzili badanie empiryczne na dwóch grupach spółek, tj. publicznych spółkach bankowych wchodzących w zakres indeksu WIG-Banki ${ }^{18}$ (które z definicji powinien cechować wysoki poziom ładu korporacyjnego) oraz spółkach budowlanych tworzących WIG-Budownictwo.

Tabela 1 przedstawia skład rad nadzorczych w publicznych spółkach bankowych. Dane przedstawione w tabeli 2 prezentują:

- stan liczbowy rad nadzorczych na 31.12.2012 r. opublikowany przez analizowane banki na ich stronach internetowych,

- minimalną liczbę niezależnych członków rad nadzorczych, którą określono w statutach lub (i) regulaminach rad nadzorczych analizowanych banków,

- rzeczywistą liczbę niezależnych członków rad nadzorczych ustaloną na podstawie opublikowanych oświadczeń analizowanych banków oraz informacji zawartych w „sprawozdaniach zarządów z działalności banków” (należy wskazać, że banki informują o rzeczywistej liczbie niezależnych członków rad nadzorczych, aczkolwiek przedmiotowa informacja jest zawarta w różnych źródłach w zależności od uznania konkretnego banku),

- rzeczywisty procentowy udział niezależnych członków rady,

- istnienie komitetów audytu w ramach rad nadzorczych ustalone na podstawie regulaminów rad nadzorczych, informacji zawartych w sprawozdaniach zarządów z działalności banków.

${ }^{18}$ W opracowaniu pominięto spółki Nova Kreditna Banka Maribor D.D. oraz Unicredit S.P.A. 


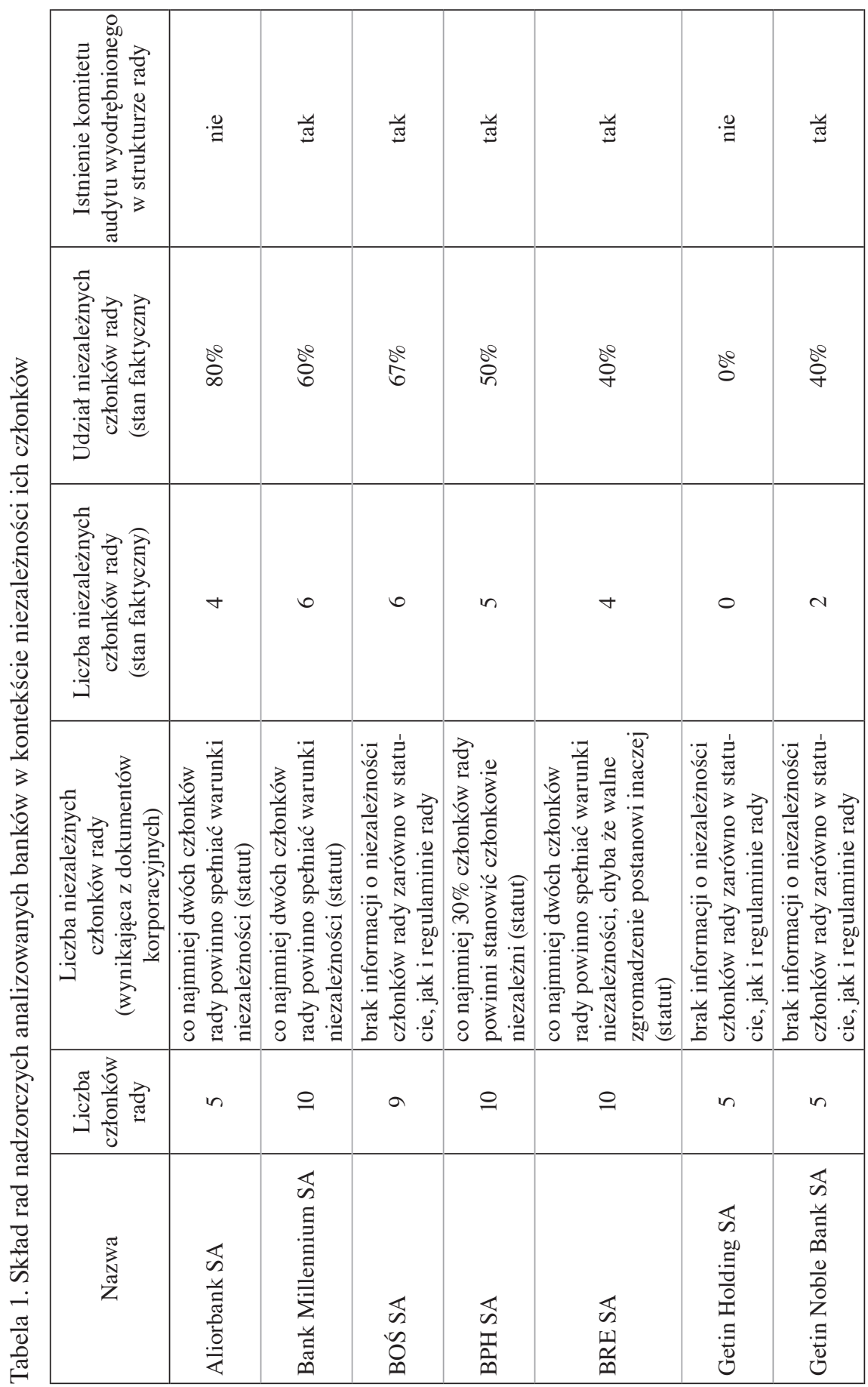




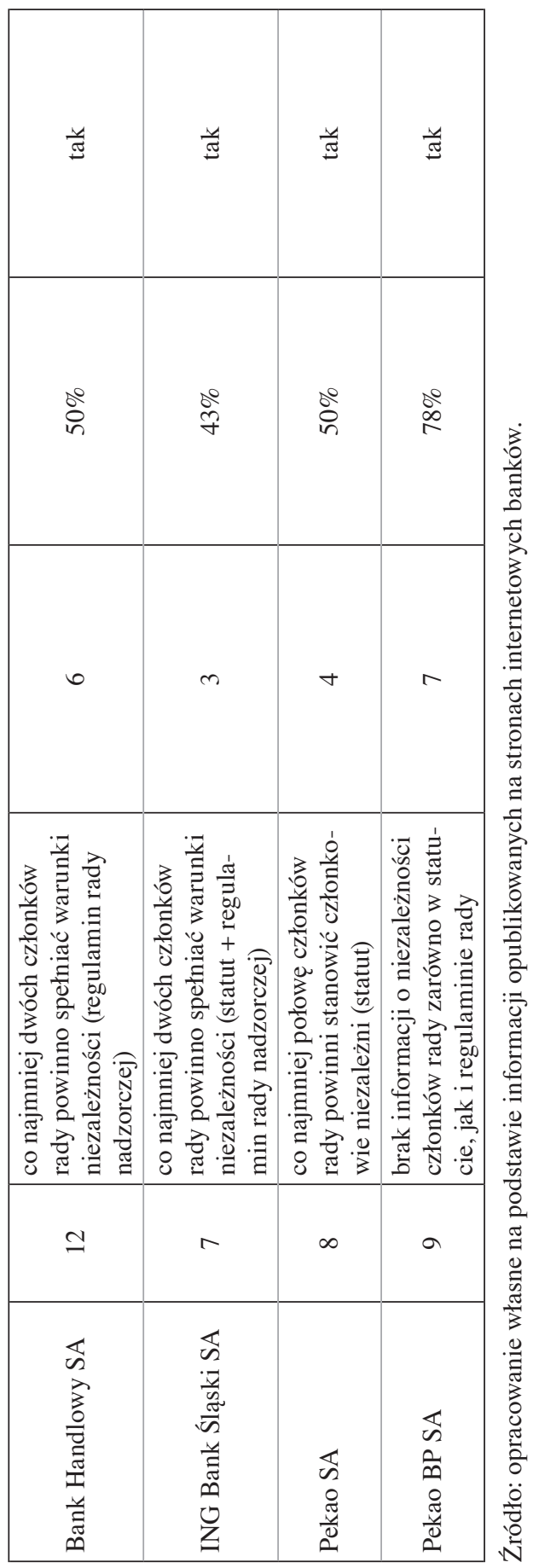




\begin{tabular}{|c|c|c|c|c|c|c|c|c|c|c|c|}
\hline 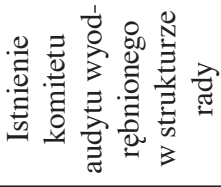 & $\cdot \stackrel{\bullet}{=}$ & 壱 & 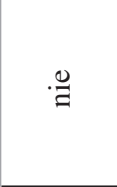 & $\stackrel{\varrho}{\exists}$ & 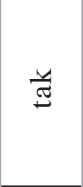 &.$\stackrel{\varrho}{\Xi}$ & 奇 & $\stackrel{\varrho}{\Xi}$ & 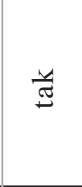 & 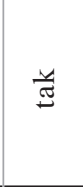 & $\stackrel{\mathscr{U}}{\exists}$ \\
\hline 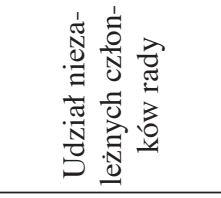 & :̊ & $\stackrel{\circ}{ٍ}$ & $8_{0}^{\circ}$ & 80 & $\begin{array}{l}\stackrel{0}{0} \\
\infty \\
\sim\end{array}$ & $\stackrel{8}{8}$ & $8^{\circ}$ & $8^{\circ}$ & 80 & $\stackrel{\sim}{\infty}$ & mे \\
\hline 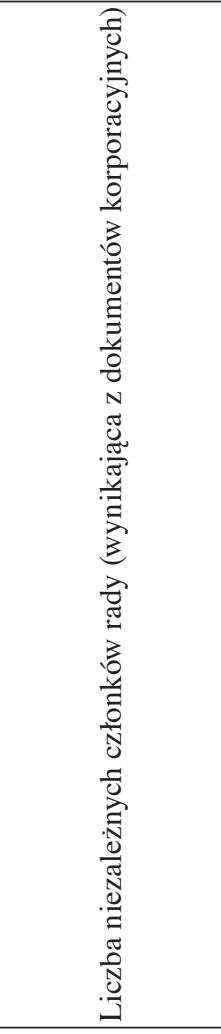 & 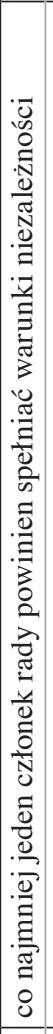 & 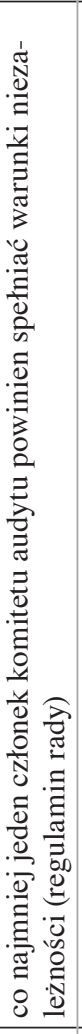 & 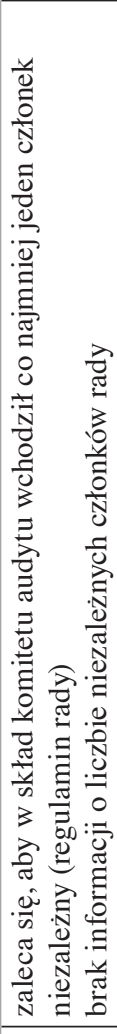 & 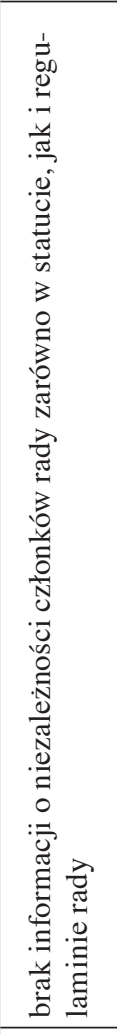 & 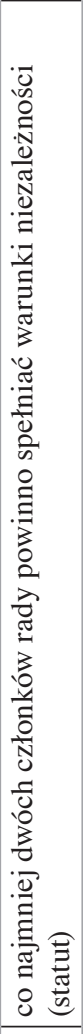 & 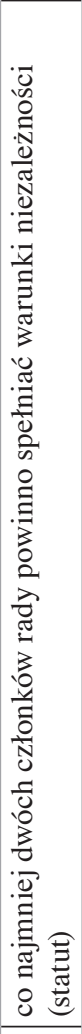 & 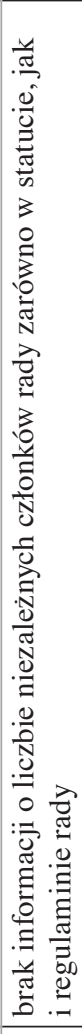 & 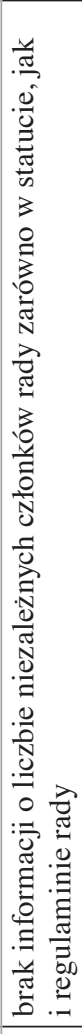 & 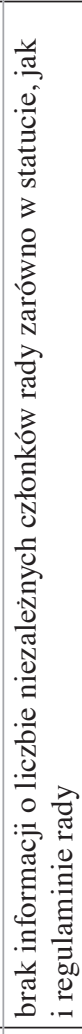 & 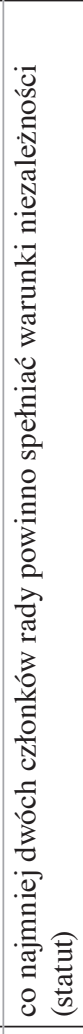 & 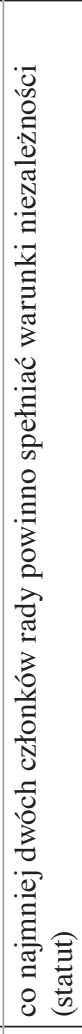 \\
\hline 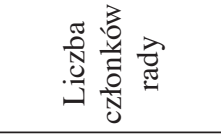 & $n$ & $a$ & $n$ & $n$ & r & $n$ & $r$ & $n$ & 0 & $r$ & 0 \\
\hline 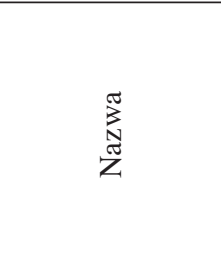 & 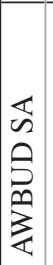 & 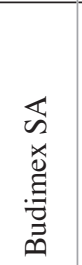 & 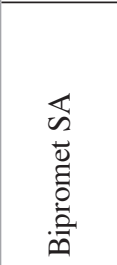 & 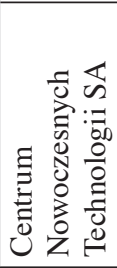 & 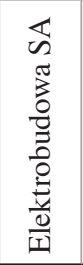 & 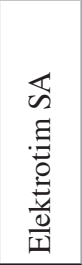 & 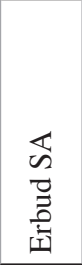 & 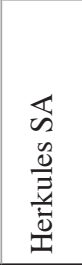 & 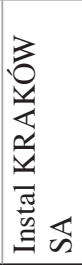 & 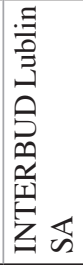 & 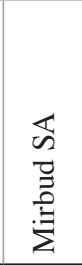 \\
\hline
\end{tabular}




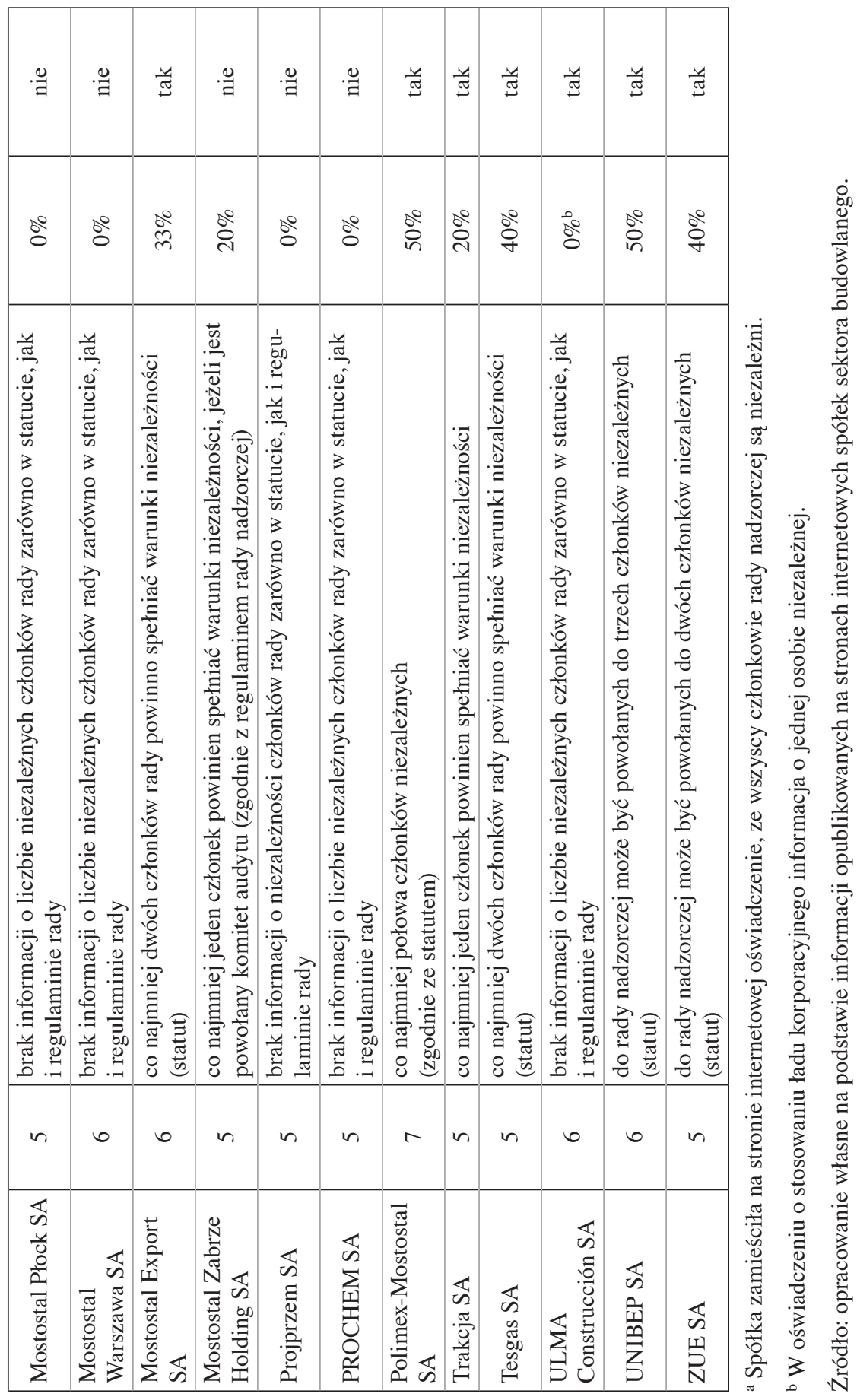


Tabela 2 przedstawia skład rad nadzorczych w spółkach tworzących WIG-Budownictwo. Uwzględniono następujące dane:

- stan liczbowy rad nadzorczych na 31.12.2012 r. opublikowany przez analizowane spółki branży budowlanej na ich stronach internetowych,

- minimalna liczba niezależnych członków rad nadzorczych, którą określono w statutach lub (i) regulaminach rad nadzorczych analizowanych spółek branży budowlanej,

- procentowy udział niezależnych członków rady ustalony na podstawie minimalnych wymogów wynikających ze statutów lub (i) regulaminów rad nadzorczych (należy wskazać, że spółki branży budowlanej tworzące WIG-Budownictwo generalnie nie publikują informacji o niezależnych członkach rad nadzorczych (poza nielicznymi wyjątkami); z tego względu autorzy przyjęli założenie, że analizowane spółki spełniają wymóg niezależności członków rad nadzorczych na poziomie minimalnym wynikającym z „Dobrych praktyk spółek notowanych na GPW"; wskazane założenie poparte zostało analizą oświadczeń badanych spółek dotyczących stosowania ładu korporacyjnego;

- istnienie komitetów audytu w ramach rad nadzorczych ustalone na podstawie regulaminów rad nadzorczych, informacji zawartych w sprawozdaniach zarządów z działalności banków.

Interpretacja uzyskanych wyników badań wymaga poczynienia pewnych założeń. Biorąc pod uwagę rolę, którą niezależni członkowie rady nadzorczej mają do odegrania w procesie rewizji finansowej, można zaryzykować pogląd, że im jest ich więcej, tym lepiej - zarówno w wartościach bezwzględnych, jak i w proporcji do ogólnej liczby członków rady. W celu dokonania interpretacji wyników badań należało przyjąć następującą nomenklaturę:

- spełnienie wymogu w stopniu wysokim: większość członków rady to członkowie niezależni i jest ich co najmniej dwóch;

- spełnienie wymogu w stopniu minimalnym: mniejszość członków rady to członkowie niezależni, lecz jest ich co najmniej dwóch;

- niespełnienie wymogu: w radzie nie ma dwóch członków niezależnych.

Rysunek 1 przedstawia relację pomiędzy liczbą członków rad nadzorczych w analizowanych bankach a liczbą członków niezależnych zasiadających w tych radach.

Na podstawie przedstawionych danych można stwierdzić, że większość banków zapewnia wymóg niezależności członków rad nadzorczych w stopniu co najmniej minimalnym. Tylko jeden bank (Getin Holding SA) nie spełnia wymogu. Wyniki przeprowadzonej analizy przedstawiono na rys. 2.

Przedstawione wyniki wskazują, że banki generalnie stosują się do zasad ładu korporacyjnego, podejmując działania na rzecz uczciwości i przejrzystości oraz poszanowania praw wszystkich akcjonariuszy niezależnie od wielkości posiada- 
nych przez nich pakietów akcji. Jest to związane z procesem budowania wartości banków i zaufania do sektora bankowego. Można pokusić się o stwierdzenie, że wynika to ze szczególnej roli banków w gospodarce i ich postrzegania przez klientów zarówno korporacyjnych, jak i indywidualnych.

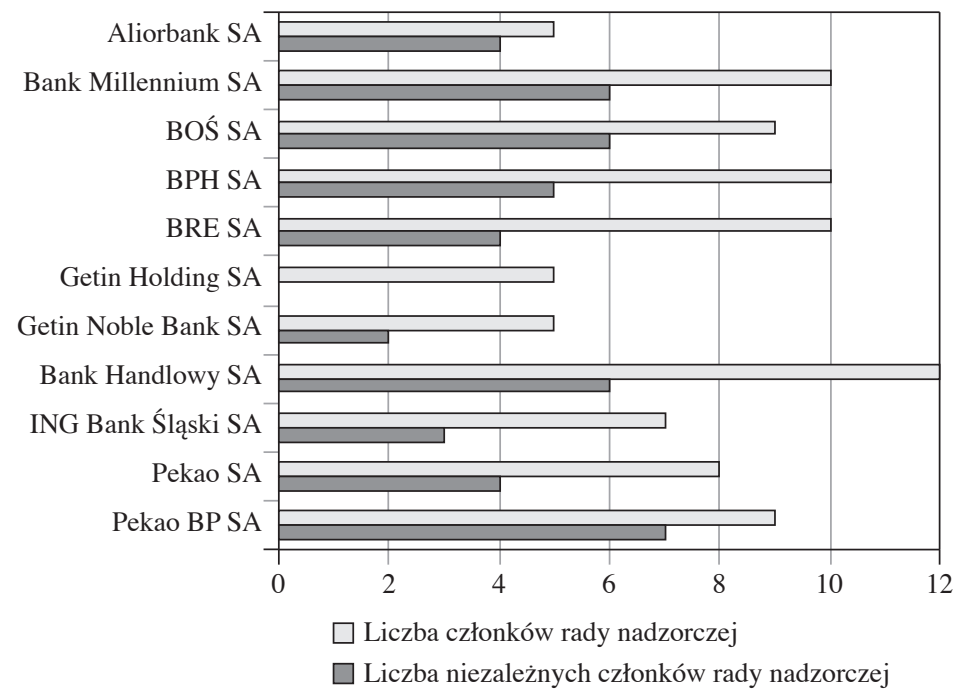

Rys. 1. Relacja pomiędzy liczbą członków rad nadzorczych a liczbą członków niezależnych zasiadających w tych radach w bankach należących do indeksu WIG-Banki na GPW w Warszawie

Źródło: opracowanie własne na podstawie danych zawartych w tabeli 1.

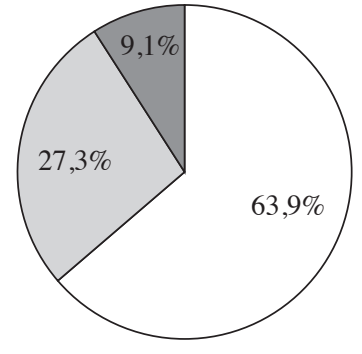

Banki spełniające wymóg niezależności członków rad nadzorczych w stopniu wysokim

Banki spełniające wymóg niezależności członków rad nadzorczych w stopniu minimalnym

Banki niespełniające wymogu niezależności członków rad nadzorczych

Rys. 2. Udział banków spełniających wymóg niezależności członków rad nadzorczych w grupie banków należących do indeksu WIG-Banki na GPW w Warszawie Źródło: opracowanie własne. 


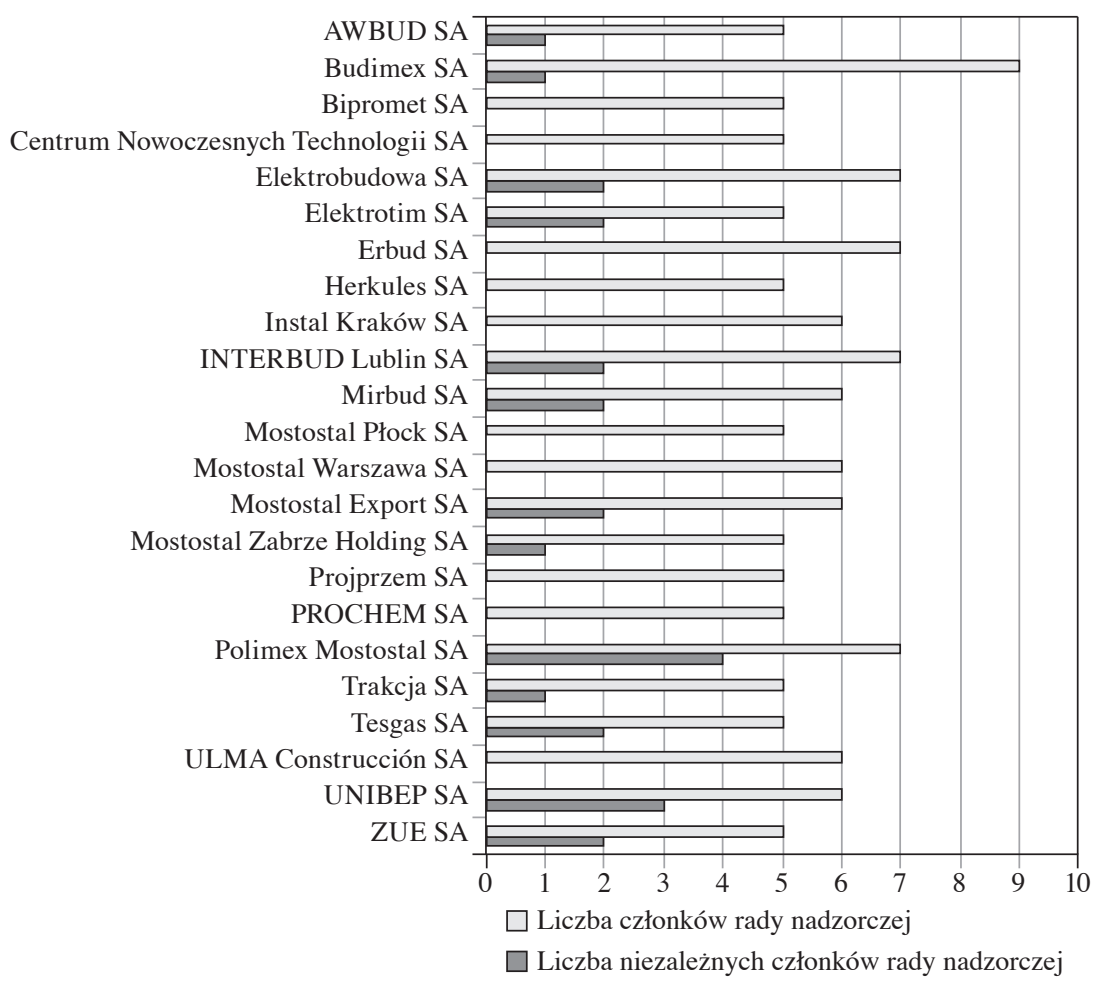

Rys. 3. Relacja pomiędzy liczbą członków rad nadzorczych a liczbą członków niezależnych zasiadających w tych radach w spółkach należących do indeksu WIG-Budownictwo na GPW w Warszawie Źródło: opracowanie własne na podstawie danych zawartych w tabeli 2.

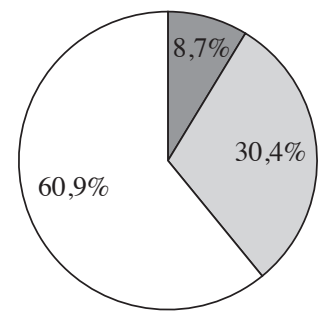

$\square$ Spółki budowlane spełniające wymóg niezależności członków rad nadzorczych w stopniu wysokim

$\square$ Spółki budowlane spełniające wymóg niezależności członków rad nadzorczych w stopniu minimalnym

$\square$ Spółki budowlane niespełniające wymogu niezależności członków rad nadzorczych

Rys. 4. Udział spółek budowlanych spełniających wymóg niezależności członków rad nadzorczych w grupie spółek budowlanych należących do indeksu WIG-Budownictwo na GPW w Warszawie

Źródło: opracowanie własne. 
O wiele gorzej wygląda sytuacja w spółkach branży budowlanej. Rysunek 3 prezentuje relację pomiędzy liczbą członków rad nadzorczych w analizowanych spółkach sektora budowlanego a liczbą członków niezależnych zasiadających w tych radach. Aż $61 \%$ spółek badanej próby nie zapewnia niezależności członków rad nadzorczych. Wyniki przeprowadzonej analizy przedstawia rys. 4.

\section{Podsumowanie}

Przedstawione wyniki badań pozwalają jednoznacznie stwierdzić, że spełnienie wymogu niezależności (choćby części) członków rad nadzorczych w spółkach publicznych notowanych na Giełdzie Papierów Wartościowych w Warszawie jest zależne od grupy badanych spółek. W przypadku spółek bankowych normatywnie określone minimum jest niejednokrotnie znacznie przekraczane, istnieją jednak przykłady skrajnie negatywne. Z kolei w przypadku spółek budowlanych sytuacja wygląda znacznie gorzej - jedynie niektóre z nich spełniają wymóg niezależności W stopniu minimalnym. W tej sytuacji niezasługującej na aprobatę pojawia się pytanie o przyczyny istniejącego stanu rzeczy.

Wydaje się, że oddziaływanie za pomocą instrukcji (wynikające z u.b.r. czy „Dobrych praktyk”) nie jest rozwiązaniem adekwatnym w polskich warunkach. Tezę tę jasno potwierdza niski poziom spełniania przez spółki publiczne norm o takim właśnie charakterze. Jeśli przyjąć merytoryczną konieczność wdrożenia postulatu wymagającego zasiadania w radach nadzorczych członków niezależnych, to należy zastosować właściwe instrumenty, tj. precyzyjne przepisy imperatywne. Nie każdy rynek kapitałowy można regulować normami instrukcyjnymi. Warto także wskazać na konieczność zwiększenia aktywności organów giełdy w zakresie egzekwowania przestrzegania „Dobrych praktyk” przez spółki publiczne.

W kontekście podstawowego problemu badawczego poruszonego w opracowaniu należy wyrazić troskę o wykorzystanie wszystkich możliwości płynących ze współpracy biegłego rewidenta z badaną jednostką. W praktyce ograniczanie liczby niezależnych członków rady nadzorczej spółki publicznej z pewnością wpływać będzie na obniżenie jakości i efektywności procesu rewizji finansowej - ze szkodą dla szeroko rozumianego obrotu gospodarczego, szczególnie w tak newralgicznym obszarze jak rynek kapitałowy.

\section{Literatura}

Andrzejewski M. [2012], Komentarz do ustawy o biegłych rewidentach i ich samorzqdzie, podmiotach uprawnionych do badania sprawozdan finansowych oraz o nadzorze publicznym, ODDK, Gdańsk. 
Dyrektywa 2006/43/WE Parlamentu Europejskiego i Rady z dnia 17 maja 2006 r. w sprawie ustawowych badań rocznych sprawozdań finansowych i skonsolidowanych sprawozdań finansowych, zmieniająca dyrektywy Rady 78/660/EWG i 83/349/EWG oraz uchylająca dyrektywę Rady 84/253/EWG, Dz.U. L 157 z 9.06.2006.

Garstka M. [2011], Rola biegłego rewidenta i jednostki przy identyfikacji ryzyka gospodarczego, w tym kontynuacji działalności, „,Rachunkowość”, nr 8.

Grzegorczyk F. [2010a], Komitet audytu jako instytucja wspomagajaca bezpieczne funkcjonowanie instytucji finansowych, „Bezpieczny Bank”, nr 1.

Grzegorczyk F. [2010b], Komitet ds. audytu - uwagi o potrzebie właściwego uregulowania instytucji w prawie polskim, „Przegląd Prawa Handlowego”, nr 11.

Kutera M. [2008], Rola audytu finansowego w wykrywaniu przestęstw gospodarczych, Difin, Warszawa.

Oplustil K. [2010], Instrumenty nadzoru korporacyjnego (corporate governance) w spółce akcyjnej, C.H. Beck, Warszawa.

Śliwińska-Grzegorczyk M. [2011], Funkcja kontrolna rachunkowości w działalności rad nadzorczych spółek publicznych - zarys problemu [w:] Współczesne aspekty realizacji kontrolnej funkcji rachunkowości, red. B. Micherda, Difin, Warszawa.

Ustawa z dnia 15 września 2000 r. Kodeks spółek handlowych, Dz.U. nr 94, poz. 1037, ze $\mathrm{zm}$.

Ustawa z dnia 18 maja 1964 r. Kodeks cywilny, Dz.U. nr 16, poz. 93 ze zm.

Ustawa z dnia 29 września 1994 r. o rachunkowości, Dz.U. 2013, poz. 330.

Ustawa z dnia 7 maja 2009 r. o biegłych rewidentach i ich samorządzie, podmiotach uprawnionych do badania sprawozdań finansowych oraz o nadzorze publicznym, Dz.U. nr 77, poz. 649 ze zm.

Zalecenie Komisji z dnia 15 lutego 2005 r. dotyczące roli dyrektorów niewykonawczych lub będących członkami rady nadzorczej spółek giełdowych i komisji rady (nadzorczej) 2005/162/WE, Dz.Urz. UE L 52.

\section{Board Member Independence as a Legal Requirement in Statutory Audits}

Employing an appropriate method of choosing an auditor together with his competence (both knowledge and ethical conduct) constitute conditio sine qua non of the efficient performance of financial audits. It should be noted that an auditor's performance can be optimised only if he finds appropriate counterparts at the entity he is to audit. Apart from management board members, particular attention should be paid to the supervisory board members. Strengthening the position of the supervisory bodies in financial reporting and audit-related issues is becoming a more and more visible trend in current legislation (e.g. article 4a of the law on accountancy). The first purpose of this paper is to find a substantive criterion by which to determine whether an auditor has an appropriate counterpart within the entity he is auditing (this is the independence of the supervisory board members). The second purpose is to check how common it is for supervisory board members to actually be independent (examples of two groups of companies listed on the Warsaw Stock Exchange are analysed).

Keywords: corporate governance, statutory auditor, supervisory board member independence, auditing. 